\title{
The Role of Internal and External Stakeholders in Higher Education System in Ukraine
}

\section{Larisa Savga}

$\mathrm{PhD}$, Professor, Trade Co-operative University of Moldova

\section{Olena Krykliy}

$\mathrm{PhD}$, Associate Professor, Head of the Teaching-Methodic Department, Sumy State University, Ukraine

\section{Konstantin Kyrychenko}

Head of International Affairs Office, Sumy State University, Ukraine

\begin{abstract}
The paper is dedicated to identifying the role of internal and external stakeholders in Higher Education system in Ukraine. Stakeholder analysis provides for identifying the most important stakeholder groups with direct and indirect influence on the HEIs. Therefore, the aim of this paper is to carry out an identification and categorization of stakeholders of HEIs. A list of stakeholders for HEIs is provided in the paper. The authors suggested deepening their stratification according to the following classification criteria: location, level of responsibility, level of influence on decision-making concerning activities of a HEI, form of performance of influence, scale of influence, financial ties, involvement status, potential for cooperation and threat, the stakeholders' stakes, types of stakeholders' interests, attributes power, legitimacy and urgency, significance level. In the article, the authors develop a model for selection and harmonization of stakeholder interests, which includes the following components: analysis and selection of key stakeholder groups, alignment of interests and needs of stakeholders and management decisions, taking into account the interests of stakeholder groups.
\end{abstract}

Keywords: higher education institutions, system of quality assurance, stakeholders, internal stakeholders, external stakeholders, stakeholder analysis.

JEL Classification: M00, M12.

(C) The Authors, 2018. This article is published with open access at Sumy State University.

\section{Introduction}

Modern universities are at the center of the intersection of interests and goals of different groups of stakeholders, which can either complement or interfere with each other. From the point of view of Stakeholder Theory, any organization, including higher education institutions (HEIs), exists to meet the needs of all stakeholders, and this is their fundamental goal. If a HEI is not oriented in its activities to the interests of stakeholders, it can hardly count on sustainable development.

Hence, our first objective is to set out a classification model for stakeholders in HEIs in Ukraine. In addition, the second objective is to put forward a model explaining selection and coordination of interests of groups of stakeholders at HEIs.

\section{Literature review}

The basic definition of a stakeholder is "any group or individual who can affect or is affected by the achievement of the organization's objectives" introduced by Freeman R. E., 1984 in the context of the development of the theory of organizations. Friedman A. L. \& Miles S., 2006 state that this definition is balanced and broad. The phrase "can affect or is affected by" includes individuals outside the firm and groups that may consider them stakeholders of an organization, without the firm considering them to be such.

The basic postulates of this theory are actively used in studies of Higher Education and ensuring its quality. In the specific case of HEIs, Stakeholder Theory may serve to explain the focus on varying communities in the environments surrounding these organisations as well as relationships between organisations and communities (Jongbloed B., Enders J. \& C. Salerno, 2008).

In the works of foreign scientists Jongbloed B., Enders J. \& C. Salerno, 2008; Bjorkquist C., 2009; Alves H., Emerson W. M. \& Raposo M., 2010; Chapleo C. \& Simms C., 2010; Matlay H., 2011; Maric I., 2013; Mainardes E., Alves H. \& Raposo M., 2012, 2013; Kettunen J., 2015; Avci Ö., Ring E., Mitchelli L., 2015; 
Pucciarelli F. \& Kaplan A., 2016; Labanauskis R. \& Ginevičius R. (2017) it is established that HEIs should identify the groups of their key stakeholders. After that, it is necessary to evaluate the effectiveness of relations with them and develop on this basis strategies for interaction with each of the selected groups.

Jongbloed B., Enders J. \& C. Salerno (2008) note the need to identify stakeholders, their structuring in terms of importance and the formation on this basis of a set of communications with them. They argue that the outcome of process of stakeholder engagement will have important implications for the university's chances for survival. A careful study of such processes, the forces that drive them and their impact on the internal work of the university seem to be both timely and warranted.

The consideration of the opinion of stakeholders in the formation of the quality assurance system of HEIs is compulsory in the European Higher Education Area. In the Standards and Guidelines for Quality Assurance in Higher Education (ESG) an important role of certain groups of stakeholders such as students, staff members and employers, has been shown. In the works of Reavill L. R. P., 1997; Rosa M. J., Sarrico C. S. \& Amaral A., 2012; Şavga L., 2013; Leisyte L. \& Westerheijden D. F., 2014; Rosa M. J. \& Teixeira P., 2014; Ulewicz R., 2017 the role of stakeholders in HEIs is analysed precisely in the context of the design of quality assurance systems, including the implementation of ESG.

In the works of Paraschivescu, A., Şavga, L., 2016 it is established that management of education quality should focus on building networks and strategic alliances between multiple parties / stakeholders: those who design, produce, evaluate the act of education in educational institutions, those who distribute continuing education, those who finance and those who benefit from quality education.

In the domestic scientific literature, studies of the role of stakeholders in the system of higher education are practically absent. In the works of Smentina N. V. \& Khusaínov R. V., 2014, Kalashnikova S. \& Lugovoi V., 2015, Panchishin S. M. \& Grin'kevich O. S., 2017, the focus is concentrated on clarifying the nature and composition of stakeholders in universities in Ukraine. In our opinion, research in this area should be intensified. This is primarily due to the need to integrate the national system of Higher Education into European and global educational space, where consideration of the interests of key stakeholders is obligatory.

A separate line of research is devoted to the study of the specifics of the influence of stakeholders in Higher Education systems of different countries.

Wit K. De \& Verhoeven J. C., 2000 characterized the participation of "stakeholders" in the internal governance of universities and colleges (hogescholen) in Flanders.

The results of study Vann M., 2012 reveal that stakeholders in Cambodian Higher Education had different perceptions of the quality. Most local stakeholders appeared to express their support for the current situation of Cambodian higher education, saying that the quality of Cambodian higher education appears to be far better than it was twenty years ago. International stakeholders, on the other hand, seemed to be very critical of the quality in Cambodian higher education, claiming that HEIs in Cambodia operated like a business enterprise, which focused more on profit, rather than ensuring quality.

Mainardes E., Alves H. \& Raposo M., 2013 carried out a case study on a Portuguese state university that sought to identify and qualify the importance of respective stakeholders through such means. A series of interviews have been held with fifteen individuals, connected with the institution, three from each hierarchical university level. Following content analysis of these interviews, a list containing 21 stakeholders was resulted, duly classified by importance. The results found students (1), the teaching and / or research staff (2), employers (3), research and development partner companies (4) and national government / ministries / accreditation bodies (5) identified as the main stakeholders.

Slabá M., 2015 identified ten most important stakeholder groups for public and private universities separately. The author identified that public universities focus mainly on students, media and Ministry of Education, Youth and Sports. Private universities understand the necessity to communicate with key stakeholder groups a little bit more than public universities. Nine stakeholder groups have been chosen by more than $60 \%$ of respondents from private universities, and six stakeholder groups have been chosen by more than $90 \%$ of the private universities involved in the survey. In the case of public universities, only 6 stakeholder groups have been chosen by more than $60 \%$ of respondents, 3 by more than $80 \%$ of respondents, and only 1 stakeholder group has been chosen by more than $90 \%$ of respondents.

Paper Sin C. \& Amaral A., 2017 reports the results of preliminary research into how Portuguese academics and employers perceive the responsibility of different higher education stakeholders - students, teaching staff, 
higher education institutions, employers, and policy-makers - for developing graduate employability. According to the results of their survey, it was determined that these holders are formally recognized as responsible for raising the level of graduates' ability to work. At the same time, actual participation of employers in internal institutional activities is low, and recognition of employers as stakeholders in higher education, as advocated by policy-makers, has yet to happen in Portugal.

Beerkens M. \& Udam M., 2017 focus on stakeholder engagement in higher education governance in Estonia, particularly in the area of quality assurance. This paper examines empirically the assumption that stakeholders differentiate in their expectations. Twelve focus group interviews with main stakeholders (university rectors, employers, academic staff, government officials, students) in Estonia demonstrate that the groups indeed have somewhat different perspectives on quality assurance, according to a predictable pattern. They link the results to a theoretical discussion on stakeholder engagement, concluding that the diversity in expectations may enrich the system, but it may also force the quality agency to clarify the limits of a public quality assurance system.

There is practically no comprehensive study of the influence of stakeholders on the activities of institutions of Higher Education in Ukraine.

Tymoshenkov I. V. and Nashchekina O. M., 2012 conducted a ranking of stakeholders on the priority of their interests for HEIs of Ukraine. Scientists have determined that now the most important are interests of a group of stakeholders, such as students and their parents. In their opinion, the power of this group is determined by HEIs' dependence on it, which is constantly growing due to negative demographic trends, the growth of competition and insufficient public financing of education. If this group does not put up real demand for quality education, HEIs will be forced to adapt their activities in accordance with their interests - to weaken the requirements for applicants and to lower the criteria for the quality of education. In such circumstances, the interests of such stakeholders as employers are less significant, since, being financially dependent on students and their parents, HEIs will give priority to the interests of the latter, and not to the interests of employers.

The researchers noted that with the functioning of such a group of stakeholders as the public administration in education, there is a problem of agency relations. Its meaning is that realization of abstract interests of the state should be carried out through activities of concrete agents - officials who have their own interests. With absence of an effective control system, the short-term goals of agents begin to dominate upon strategic goals of a society, while realization of state interests gradually becomes a realization of the economic interests of individual officials.

In our opinion, the results of the study, obtained by Tymoshenkov I. V. and Nashchekina O. M., 2012, make it possible to explain the general tendencies of development of education in Ukraine and determine the reasons for lowering the quality of secondary and professional education of students.

The conclusions of the scholars on the ineffective participation of government bodies of higher education are confirmed by the Analytical Report "Monitoring the integration of the Ukrainian system of higher education into the European area of higher education and scientific research". It states that, "... the decisive role in designing the quality assurance system is played by public administration, and the value of other stakeholders is quite nominal. As a result, the key setting of educational institutions is the success of formal reporting to state control bodies, which, in the absence of motivation and transparency, is highly likely to corrupt corruption".

The monitoring determined that "the characteristic features of the current situation in the system of higher education in Ukraine are the practical absence of a real involvement of external stakeholders to the development and implementation of institutional strategies of HEIs, as well as their corresponding connection with the strategic documents of the national educational policy".

The report "Reform of higher education in Ukraine: the implementation of the profile law in 2014-2016" determines that the domestic Higher Education system functions in isolation from the interests of employers. They are practically not involved in the development of academic programmes of universities, as well as in the professional training of students in a form of internships with their subsequent employment according to the study area.

Partly, the issues of engaging stakeholders to form and develop internal quality assurance systems in Ukrainian universities were studied in the context of implementation of international project "Quality Assurance System in Ukraine: Development on the Base of ENQA Standards and Guidelines" in the framework of ERASMUS+ Programme. It started with an exploratory research in the form of a survey of HEIs in Ukraine on the state of 
development of an internal quality assurance system. 217 HEIs participated in the survey, 104 of which are universities, 31 institutes (academies), 66 colleges, and 16 other educational institutions.

Characteristics of the forms of stakeholder participation in the internal quality assurance system of Ukrainian HEIs are presented in Figure 1.

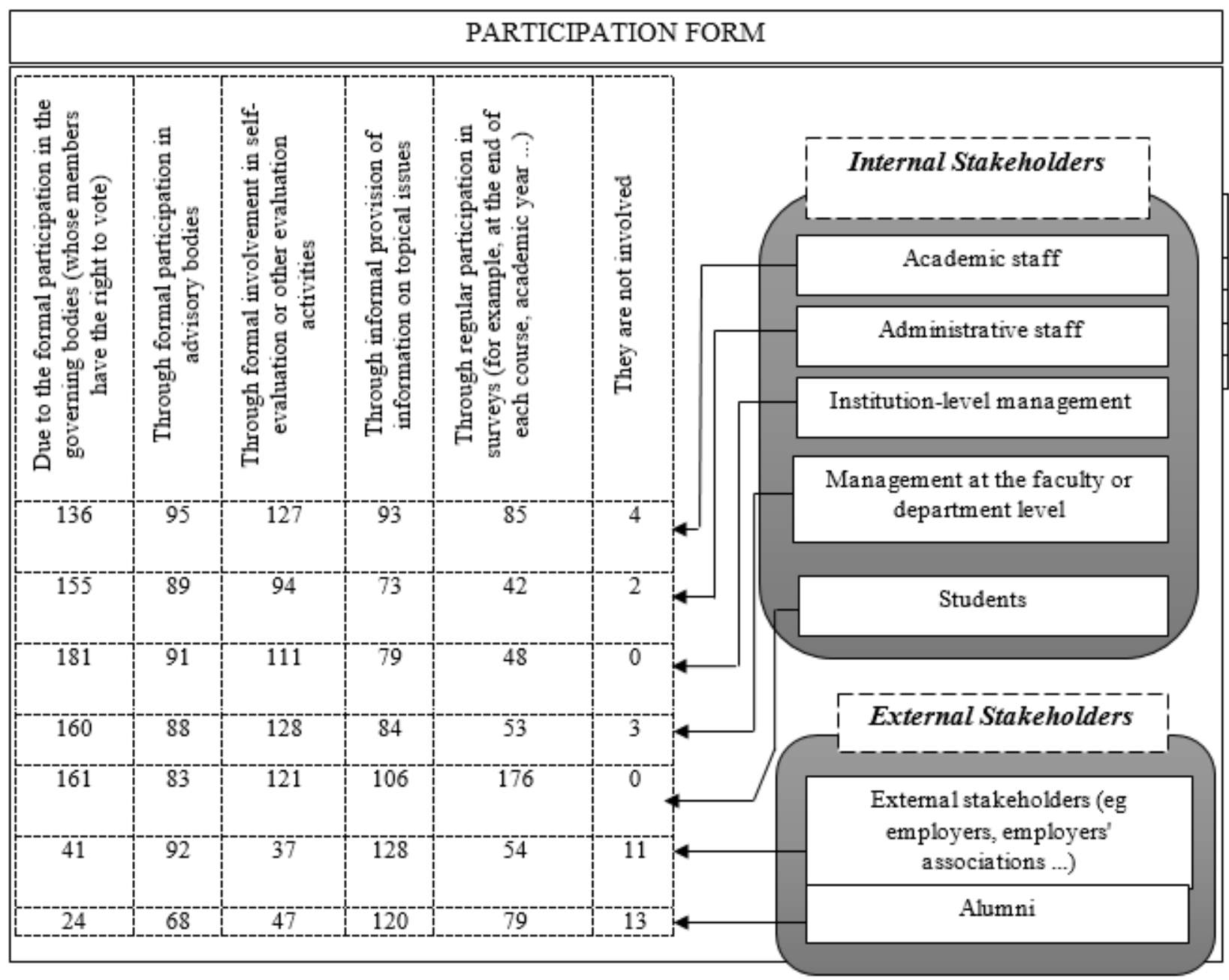

Figure 1. Characteristics of the forms of stakeholders' participation in the internal quality assurance system of Ukrainian HEIs

The obtained data makes it possible to draw a number of positive conclusions about the participation of students, as main consumers, in internal quality assurance systems of HEIs:

through formal participation in management bodies, in addition to administrative staff, management at the level of the institution and the faculty, 161 universities attracted students;

students of 121 Ukrainian universities are involved in the self-assessment of the quality of educational activities or other evaluation activities;

$>$ through informal provision of information on topical issues of quality assurance of educational activities, students (106 HEIs), employers (128 HEIs), graduates (120 HEIs) are actively involved;

regular questioning of students about the quality of educational activities is conducted in 176 HEIs.

However, along with this, a number of shortcomings have been revealed:

a low level of involvement of external stakeholders (graduates and employers) in the form of formal participation in advisory bodies. This does not allow to fully take into account the current demands of the labour market for the quality of training for higher education applicants;

$>$ employers and graduates are involved in processes of self-assessment or other evaluation activities, only at 37 and 47 HEIs in Ukraine, respectively; 
only 85 respondents indicated that academic staff participates in regular surveys on the processes of ensuring the quality of education. This indicates the need for a more active involvement of faculty members in the functioning of the internal quality assurance system.

The results of this survey also confirm the insufficient level of stakeholder involvement in the design, approval, monitoring and revision of academic programmes (Figure 2).

\begin{tabular}{|c|c|c|}
\hline \multicolumn{2}{|c|}{ PARTICIPATION FORM } \\
\hline \hline Percentage of respondents who chose the answer, $\%$ \\
\hline Participation in program \\
development processes is \\
formalized & Pevelopment of programs is & not formalized \\
\hline $28,0 \%$ & $39,7 \%$ & Academic staff \\
\hline $69,6 \%$ & $37,4 \%$ & Administrative staff \\
\hline $78,0 \%$ & $44,4 \%$ \\
\hline $32,7 \%$ & $56,1 \%$ \\
\hline
\end{tabular}

Figure 2. Stakeholder involvement in the design, approval, monitoring and revision of academic programmes at Ukrainian HEIs

The presented data shows that in the formalized processes of the development of academic programmes and curricula, internal stakeholders play the dominant role. Thus, administrative personnel is involved in $69,6 \%$ of HEIs, academic staff - in $78 \%$.

The level of involvement of students and external stakeholders is low, namely:

students are involved in the formation of academic programmes and curricula in $28 \%$ of HEIs

external stakeholders (employers / regional authorities / chamber of commerce, etc.) - in 32,7\% of HEIs; graduates - in $9,8 \%$ of HEIs.

Results of the multi-country project ALIGN (Achieving and checking the alignment between academic programmes and Qualification Frameworks) of the EU Tempus Programme revealed passive attitude of students towards university internal quality assurance system in general and the procedures of academic programmes review in particular as well as partial introduction of mechanisms of cooperation with external stakeholders.

\section{Methodology}

The article is prepared using the theoretical approach. It contains the analysis of the literature on HEIs stakeholders, quality assurance systems and issues concerning development of higher education in Ukraine. The authors' conclusions are based on the results of survey of HEIs in Ukraine on the state of development of an internal quality assurance system.

\section{Results}

The application of Stakeholder Theory to the management of HEIs provokes identification of all stakeholders, their interests and expectations. 
Based on the results of the study Dew John R., 1997; Burrows J., 1991; Jongbloed B., Enders J. \& Salerno C., 2008; Smentina N. V. \& Khusaínov R. V., 2014; Panchishin S. M. \& Grin'kevich O. S., 2017, stakeholders in HEIs are shown in Figure 1 in Appendix.

As a result of identification of stakeholders, a HEI receives an exhaustive list of its stakeholders, which is obligatory for subsequent analysis and development of a strategy for interaction with them.

The next stage involves the structuring of stakeholders by a number of additional classification characteristics.

The external and internal stakeholder category is the most commonly used approach. In case of HEIs stakeholders also are mostly divided into internal and external (Melewar T.C. \& Akel S., 2005; Smentina N. V. \& Khusaínov R. V., 2014; Panchishin S. M. \& Grin'kevich O. S., 2017; Slabá M., 2015). At once, Burrows J., 1999 focused attention that the external and internal stakeholder category does not always help with the groups of stakeholders in academic institutions.

For example, students can be viewed as external stakeholders from enrolment perspective. However, they can be viewed as internal stakeholders as they have impact on the scholarly work done in the university.

In order to achieve success, the aims of internal stakeholders, the first degree environment, ought to be compatible with the aims of external stakeholders (the second degree environment) (Ulewicz V., 2017). In addition to the basic division of stakeholders into external and internal, a number of additional classification characteristics are singled-out for in-depth study of their influence on HEIs.

The generalization of characteristics of classification of HEIs stakeholders is given in Table 1 .

Table 1. Classification of HEIs stakeholders

\begin{tabular}{|c|c|c|}
\hline No. & $\begin{array}{l}\text { Classification } \\
\text { criteria }\end{array}$ & Types of HEIs stakeholders \\
\hline 1. & Location & $\begin{array}{l}\text { internal stakeholders operating within the HEI; } \\
\text { interface stakeholders that interact with the external environment; } \\
\text { the activities of the HEI. }\end{array}$ \\
\hline 2. & $\begin{array}{l}\text { Level of } \\
\text { responsibility }\end{array}$ & $\begin{array}{l}\text { primary stakeholders (with formal relationships): } \\
\text { 1) internal stakeholder groups of HEIs represent stakeholder groups that are crucial for } \\
\text { survival of HEIS and involve stakeholder groups that bear risk and investment connected } \\
\text { to universities; } \\
\text { 2) external stakeholder groups of HEIs include stakeholder groups that are essential for } \\
\text { survival of HEIs, despite not being in direct close relation with the HEI. These stakeholder } \\
\text { groups are in an indirect connection, but have a direct influence on survival of universities. } \\
\end{array}$ \\
\hline 3. & $\begin{array}{l}\text { Level of } \\
\text { influence on } \\
\text { decision making } \\
\text { on the activities } \\
\text { of the HEI }\end{array}$ & $\begin{array}{l}\text { stakeholders, who directly take and influence decision-making (strong influence); } \\
\text { stakeholders, whose interests are taken into account when making decisions (medium } \\
\text { impact); } \\
\text { influence). }\end{array}$ \\
\hline 4. & $\begin{array}{l}\text { Form of } \\
\text { manifestation of } \\
\text { influence }\end{array}$ & $\begin{array}{l}>\text { overt stakeholders; } \\
>\text { latent stakeholders. }\end{array}$ \\
\hline 5. & $\begin{array}{l}\text { Scale } \\
\text { influence }\end{array}$ & $\begin{array}{l}>\text { influence HEIs as a whole; } \\
>\text { affect the individual aspects of the activity of a HEIs. }\end{array}$ \\
\hline 6. & Financial ties & $\begin{array}{l}>\text { commercial stakeholders; } \\
>\text { non-commercial stakeholders. }\end{array}$ \\
\hline 7. & $\begin{array}{l}\text { Involvement } \\
\text { status }\end{array}$ & $\begin{array}{l}\text { active stakeholders are those individuals or groups who are actively engaged in the } \\
\text { institution; } \\
\text { relations with the institution, but they have been affected by past actions or can be affected } \\
\text { by the future actions of the institution. }\end{array}$ \\
\hline 8. & $\begin{array}{l}\text { Potential for } \\
\text { cooperation and } \\
\text { threat }\end{array}$ & $\begin{array}{l}\text { "low cooperation/high threat"; } \\
\text { "high threat / high cooperation"; } \\
\text { "low cooperation / low threat"; } \\
\text { "high cooperation / low threat". }\end{array}$ \\
\hline
\end{tabular}


Table 1 (cont.). Classification of HEIs stakeholders

\begin{tabular}{|c|c|c|c|c|}
\hline 9. & $\begin{array}{l}\text { The } \\
\text { stakeholders' } \\
\text { stakes }\end{array}$ & \multicolumn{3}{|c|}{$\begin{array}{l}\text { stakeholders have ownership stakes; } \\
\text { stakeholders have economic dependence; } \\
\text { stakeholders have social stakes; } \\
\text { stakeholders have scholarship stakes; } \\
\text { stakeholders have moral stakes; } \\
\text { stakeholders have personal stakes. }\end{array}$} \\
\hline 10. & $\begin{array}{l}\text { Types of } \\
\text { interests } \\
\text { stakeholders }\end{array}$ & \multicolumn{3}{|c|}{$\begin{array}{l}>\text { formal interests; } \\
>\text { economic interests; } \\
>\text { political interests. }\end{array}$} \\
\hline \multirow{3}{*}{11.} & \multirow{3}{*}{$\begin{array}{l}\text { Attributes } \\
\text { power, } \\
\text { legitimacy, } \\
\text { urgency }\end{array}$} & $\begin{array}{l}>\text { have one } \\
\text { attribute }\end{array}$ & $\begin{array}{l}>\text { latent } \\
\text { stakeholders }\end{array}$ & $\begin{array}{l}>\text { dormant (attribute power); } \\
>\text { discretionary (attribute legitimacy); } \\
>\text { demanding (attribute urgency). }\end{array}$ \\
\hline & & $\begin{array}{l}>\text { have two } \\
\text { attributes }\end{array}$ & $\begin{array}{l}>\text { expectant } \\
\text { stakeholders }\end{array}$ & $\begin{array}{l}>\text { dominant (attributes power and legitimacy); } \\
>\text { dependent (attributes urgency and legitimacy); } \\
>\text { dangerous (attributes urgency and power). }\end{array}$ \\
\hline & & $\begin{array}{ll}\text { have three } \\
\text { attributes }\end{array}$ & \multicolumn{2}{|c|}{$>$ definitive stakeholders } \\
\hline 12. & $\begin{array}{l}\text { Significance } \\
\text { level }\end{array}$ & \multicolumn{3}{|c|}{$\begin{array}{l}>\text { definitive stakeholders; } \\
>\text { expectant stakeholders; } \\
>\text { latent stakeholders. }\end{array}$} \\
\hline
\end{tabular}

Source: elaborated by the authors based on (Blair J. D., Fottler M. D., 1990; Clarkson M., 1995; Mitchell R. C., Agle B. R. \& Wood D. J., 1997; Burrows J., 1999; Melewar T. C. \& Akel S., 2005; Jongbloed B., Enders J. \& Salerno C., 2008; Mainardes E., Alves H. \& Raposo M., 2013; Maric I., 2013; Slabá M., 2015; Barishevs'ka İ. V. \& Korabakhína A. YU., 2016).

We propose to allocate additional subgroups of stakeholders, since their characteristics can be very significant and specific. This will make it possible to understand how significant is the impact of stakeholders and what further steps should be taken to effectively interact with them.

Key factors that determine the relative importance of different stakeholder groups in different areas of university activity:

direct impact on student recruitment and satisfaction. The key stakeholders grouped into those with direct, less direct or partial influence, and those with only an indirect or minimal impact;

$>$ impact on the university's policies and strategies. These stakeholders are broken down into three groups based on their influence. It may be proposed that those with high impact on strategies and policies needed great attention due to their power to influence strategic direction;

direct impact on the university's income, such as students and funding bodies. These groups were seen to have power and influence on the HEI and are therefore core to its development (Chapleo C. and Simms C., 2010).

The identification of the stakeholders of the HEI ends with the prioritization of stakeholder groups and personification of their interests. At the same time, the specific interests of stakeholders directly to a HEI should be reflected but not typical for all HEIs.

In order to ensure the sustained functioning, HEIs cannot focus on meeting the interests of a particular stakeholder group, regardless of the interests of others. At the end, this may lead to a loss of competitive position in the educational services market and a decrease in its quality. Taking this into account, a model for selection and coordination of the interests of stakeholders of HEIs was developed (Figure 4). 


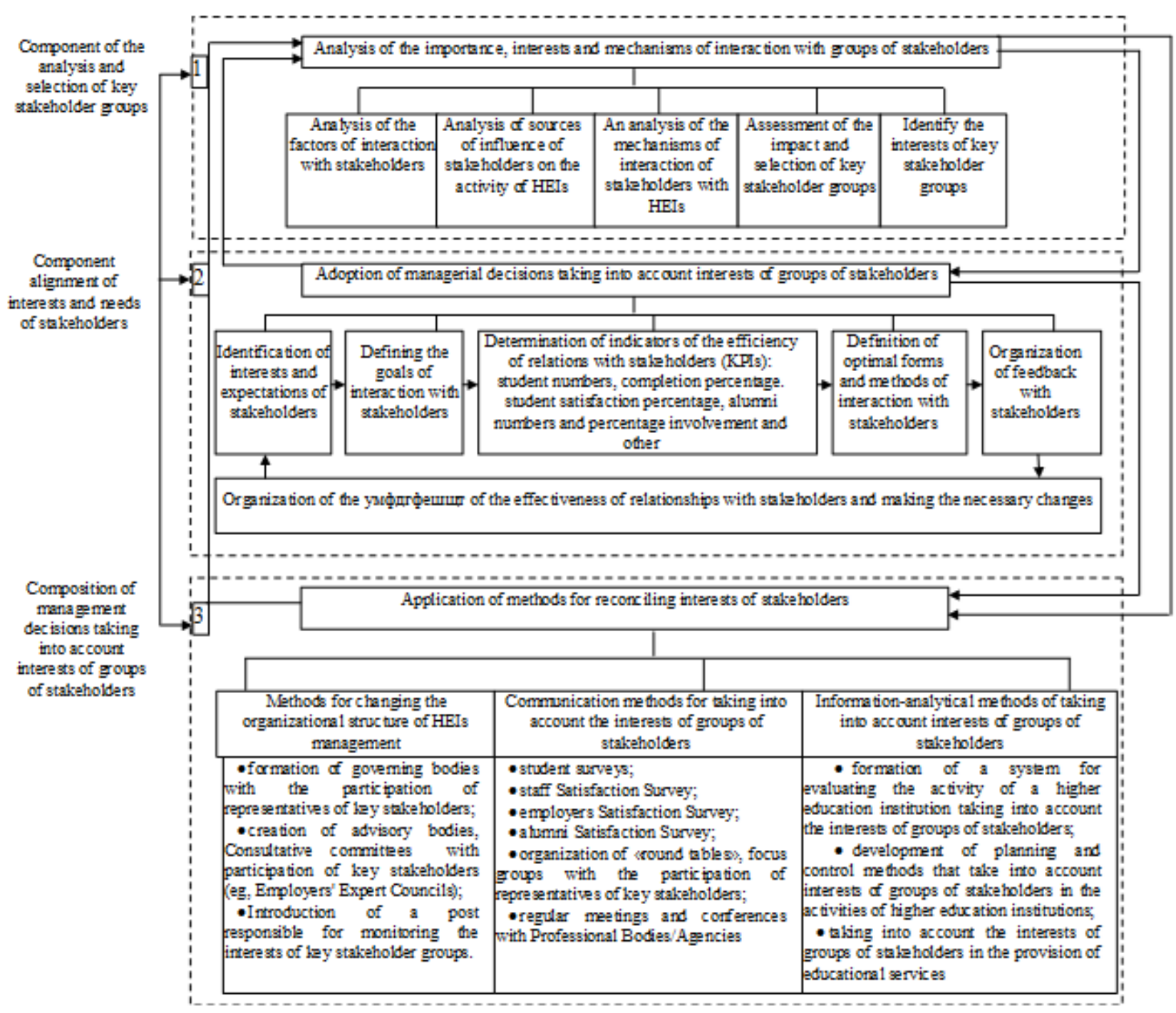

Figure 4. Model for selection and coordination of the interests of stakeholders of HEIs

\section{Conclusions and discussion}

A modern university cooperates with a large number of groups of stakeholders, and its main goal is to identify the key ones and meet their needs.

Although identification and classification of HEIs stakeholders is widely covered in foreign literature, its application in the context of Ukrainian higher education standards is less studied, and this article aims to identification and prioritization of stakeholders for a Ukrainian university.

In the article it has been defined that in a HEI, a stakeholder analysis should start with identification of all possible stakeholders: entities with regulatory powers, clients (students, employers, society in general), suppliers, employees, competitors etc. The authors also identified the necessity to classify the stakeholders according to different perspectives, including location, level of responsibility, level of influence on decision making, form of manifestation of influence, scale of influence, financial ties, involvement status, potential for cooperation and threat, the stakeholders' stakes, types of interests and other.

Based on the results of the generalization of studies on governance issues of higher education stakeholders, these shortcomings and unresolved problems have been highlighted:

models and methods for identification and classification of higher education stakeholders are based only on few aggregated characteristics; 
the goals and interests of stakeholders are generally considered in the context of the activities of universities in general, and not in the context of their individual aspects, in particular internal quality assurance systems; assessment of interests, degree of involvement and power of stakeholders is usually carried out by expert methods without validity of assessment scales and verification of reliability.

These are incentives to develop more effective methods for identifying stakeholders of higher education, their evaluation, and as a result, to better meet their needs.

Authors have developed a model for selection and coordination of the interests of stakeholders of HEIs. It consists of the following components: analysis and selection of key stakeholder groups; alignment of interests and needs of stakeholders; formation of management decisions taking into account interests of groups of stakeholders. This model can be used by representatives of HEIs to integrate the interests of stakeholder groups into the management system and strategic planning.

The direction of future research is the application of stakeholder analysis to higher education in Ukraine, since there have been no systematic studies of the identification and prioritization of stakeholders in private and public institutions of higher education.

\section{References}

1. Alves, H., Mainardes, E. W., \& Raposo, M. (2010). A relationship approach to higher education institution stakeholder management. Tertiary Education and Management, 16(3), 159-181.

2. Avci Ö., Ring E., Mitchelli L. (2015). Stakeholders in U.S. higher education: an analysis through two theories of stakeholders. Resource document. http://dergipark.gov.tr/download/article-file/323147. Accessed 25 December 2017.

3. Bary`shevs`ka, I. V., Korabaxina, Yu. (2016). Osobly`vosti vply`vu stejkxolderiv na rozvy`tok osvitn`ogo prostoru vy`shhogo navchal nogo zakladu [Features of the influence of stakeholders on the development of the educational space of a higher educational institution]. Resource document. http://217.77.213.157:8080/jspui/bitstream/123456789/1910/1/stattia_Barishevskaya_Korabahina_2016.p df. Accessed 25 December 2017.

4. Beerkens M., Udam M. (2017). Stakeholders in Higher Education Quality Assurance: Richness in Diversity? Resource document. Higher Educat ion Policy. https://doi.org/10.1057/s41307-016-0032-6. Accessed 25 December 2017.

5. Bjørkquist, C. (2009). Stakeholder Influence in Higher Education - Old Ideas in New Bottles? Resource document. Dissertation Karlstad University Studies. http://www.divaportal.org/smash/get/diva2:241378/FULLTEXT02.pdf. Accessed 25 December 2017.

6. Blair, J.D., Fottler M.D (1990). Challenges in Health Care Management: Strategic Perspectives for Managing Key Stakeholders. San Francisco: Jossey-Bass. 408 p.

7. Burrows, J. (1999). Going Beyond Labels: A Framework for Profiling Institutional Stakeholders. Contemporary Education, 70(4), 5-10.

8. Chapleo, C., Simms, C. (2010). Stakeholder analysis in higher education A case study of the University of Portsmouth. Resource document. https://doi.org/10.1080/13603100903458034. Accessed 25 December 2017.

9. Clarkson, M. (1995). A stakeholder framework for analysing and evaluating corporate social performance. Academy of Management Review, 20(1), 92-117.

10.De Wit, K., Verhoeven, J. C. (2000). Stakeholders in universities and colleges in Flanders. European Journal of Education, 35(4), 421-437.

11.Development of the Quality Assurance System for Higher Education in Ukraine: Information and Analytical Review. General edition by Kalashnikova S., Lukhovii V. (2015). Resource document. https://ihed.org.ua/images/biblioteka/Rozvitok_sisitemi_zabesp_yakosti_VO_UA_2015.pdf. Accessed 25 December 2017.

12.Dew, John. R. (1997). Quality-Centered Strategic Planning: A Step-By-Step Guide (Productivity's Shopfloor). New York, Quality Resources Press. 240 p.

13.Freeman, R. E. (1984). Strategic Management: A Stakeholder Approach. Boston, Pitman. 275 p.

14.Friedman, A. L., Miles, S. (2006). Stakeholders: Theory and Practice. Oxford, Oxford University Press. 360 p.

15.Jongbloed, B., Enders, J., \& Salerno, C. (2008). Higher education and its communities: Interconnections, interdependencies and a research agenda. Resource document. Higher education, https://doi.org/10.1007/s10734-008-9128-2. Accessed 25 December 2017.

16.Kettunen, J. (2015). Stakeholder relationships in higher education. Resource document. Tertiary Education and Management. https://doi.org/10.1080/13583883.2014.997277. Accessed 25 December 2017. 
17.Leisyte L., Westerheijden D.F. (2014) Stakeholders and Quality Assurance in Higher Education. In: Eggins H. (eds) Drivers and Barriers to Achieving Quality in Higher Education. Rotterdam, SensePublishers, 182 p.

18.Mainardes, E., Alves, H., \& Raposo, M. (2012). A model for stakeholder classification and stakeholder relationships. Resource document. Management Decision. https://doi:10.1108/00251741211279648. Accessed 25 December 2017.

19.Mainardes, E., Alves, H., \& Raposo, M. (2013). Identifying stakeholders in a Portuguese university: a case study. Resource document. Revista de Educación. https://doi:10.4438/1988-592X-RE-2012-362-167. Accessed 25 December 2017.

20.Maric, I. (2013). Stakeholder analysis of higher education institutions. Resource document. Interdisciplinary Description of Complex Systems. https://doi: 10.7906/indecs.11.2.4. Accessed 25 December 2017.

21.Matlay, H. (2011). The influence of stakeholders on developing enterprising graduates in UK HEIs. Resource document. International Journal of Entrepreneurial Behavior \& Research. https://doi.org/10.1108/13552551111114923. Accessed 25 December 2017.

22.Melewar, T. C., Akel, S. (2005). The role of corporate identity in the higher education sector: A case study. Resource document. Corporate Communications: An International Journal. https:// doi: 10.1108/13563280510578196. Accessed 25 December 2017.

23.Mitchell, R. K., Agle, B. R., \& Wood, D. J. (1997). Towards a theory of stakeholder identification and salience: defining the principle of who and what really counts. Resource document. http://www.jstor.org/stable/pdfplus/259247.pdf. Accessed 25 December 2017.

24.Monitory`ng integraciyi ukrayins`koyi sy`stemy` vy`shhoyi osvity` v Yevropejs`ky`j prostir vy`shhoyi osvity` ta naukovogo doslidzhennya: monitory`ng. doslidzh. : analit. zvit [Monitoring the integration of the Ukrainian higher education system into the European space of higher education and research] / Mizhnarod. blagod. Fond "Mizhnarod. Fond doslidzh. osvit. polity'ky"'. Ky`yiv, Takson, 2014, 144 (In Ukrainian).

25.Panchy`shy`n, S. M., Gry`n`kevy`ch, O. S. (2017). Ponyattyevy`j aparat insty`tucijnogo analizu konkurentospromozhnosti sy`stemy` vy`shhoyi osvity` [The Conceptual Apparatus of Institutional Analysis of the Competitiveness of the Higher Education System]. Ekonomika rozvy 'tku, 1(81), 50-58. (In Ukrainian).

26.Paraschivescu, A., Şavga, L. (2016). Quality Education. Resource document. Economy Transdisciplinarity Cognition. http://www.ugb.ro/Downloads/Info\%20Studenti /20162017/etc2016no2/03_Paraschivescu,Savga.pdf. Accessed 25 December 2017.

27.Pucciarelli, F., Kaplan, A. (2016). Competition and strategy in higher education: Managing complexity and uncertainty. Resource document. Business Horizons. https://doi.org/10.1016/j.bushor.2016.01.003. Accessed 25 December 2017.

28.Reavill, L. R. P. (2009). Quality assessment and the stakeholder model of higher education. Resource document. Total Quality Management. https://doi.org/10.1080/09544129710143. Accessed 25 December 2017.

29.Reform of higher education in Ukraine: the implementation of the profile law in 2014-2016. Resource document. http://parlament.org.ua/wp-content/uploads/2016/12/HE-shadow-report-final.pdf. Accessed 25 December 2017.

30.Rosa, M. J., Teixeira, P. (2014). Policy reforms, Trojan horses, and imaginary friends: The role of external stakeholders in Internal Quality Assurance Systems. Higher Education Policy, 27(2), 219-237.

31.Rosa, M. J., Sarrico, C. S. and Amaral, A. (2012). Implementing Quality Management Systems in Higher Education Institutions, Quality Assurance and Management. In Savsar, M., Ed., InTech JanezaTrdine, Rijeka, pp. 129-146.

32.Şavga, L. (2013). Quality Assurance of Higher Education in Terms of the National Education Performance and Competitiveness Growth. Economy Transdisciplinarity Cognition. Bacău, România: George Bacovia University Publishing House, 16(2), 43-48. ISSN 2068 - 7389. Available: http://www.ugb.ro/etc/etc2013no2/09_Savga.pdf.

33.Sin, C., Amaral, A. (2017). Academics' and employers' perceptions about responsibilities for employability and their initiatives towards its development. Resource document. https://doi.org/10.1007/s10734-0160007-y. Accessed 25 December 2017.

34.Slabá, M. (2015). Stakeholder Groups of Public and Private Universities in the Czech Republic Identification, Categorization and Prioritizatio. Resource document. Review of economic perspectives, 15(3), 305-326. 
35.Smenty`na, N.V., Xusainov, R.V. (2014). Social’na vidpovidal`nist`vy`shhy`x navchal`ny`x zakladiv: konceptual `ny $\mathrm{j}$ analiz [Social responsibility of higher educational institutions: conceptual analysis]. Naukovy`j visny`k Xersons kogo derzhavnogo universy`tetu, 9(2), 20-25. (In Ukrainian).

36.Standards and Guidelines for Quality Assurance in the European Higher Education Area (ESG). (2015). Resource document. http://www.enqa.eu/wp-content/uploads/2015/11/ESG_2015.pdf. Accessed 25 December 2017.

37.Ty`moshenkov, I. V., Nashhekina, O. M. (2012). Sub'yekty`, agenty`, aktory` i stejkxoldery` v ekonomichny`x doslidzhennyax osvity` [Subjects, Agents, Actors and Stakeholders in Economic Studies in Education]. Vcheni zapy 'sky' Xarkivs 'kogo gumanitarnogo universy `tetu "Narodna ukrayins "ka akademiya», 18(1), 167-176. (In Ukrainian).

38.Ulewicz, R. (2017). The role of stakeholders in quality assurance in higher education. Resource document. Human Resources Management \& Ergonomics. https://www.researchgate.net/publication/317301877_The_role_of_stakeholders_in_quality_assurance_in _higher_education. Accessed 25 December 2017.

39. Vann, M. (2012). Stakeholders' perceptions of quality in Cambodian higher education, Ph.D. Dissertation, RMIT University, Melbourne, Australia. Resource document. http://researchbank.rmit.edu.au/eserv/rmit:160093/Vann.pdf\&gathStatIcon=true. Accessed 25 December 2017. 


\section{Appendix}

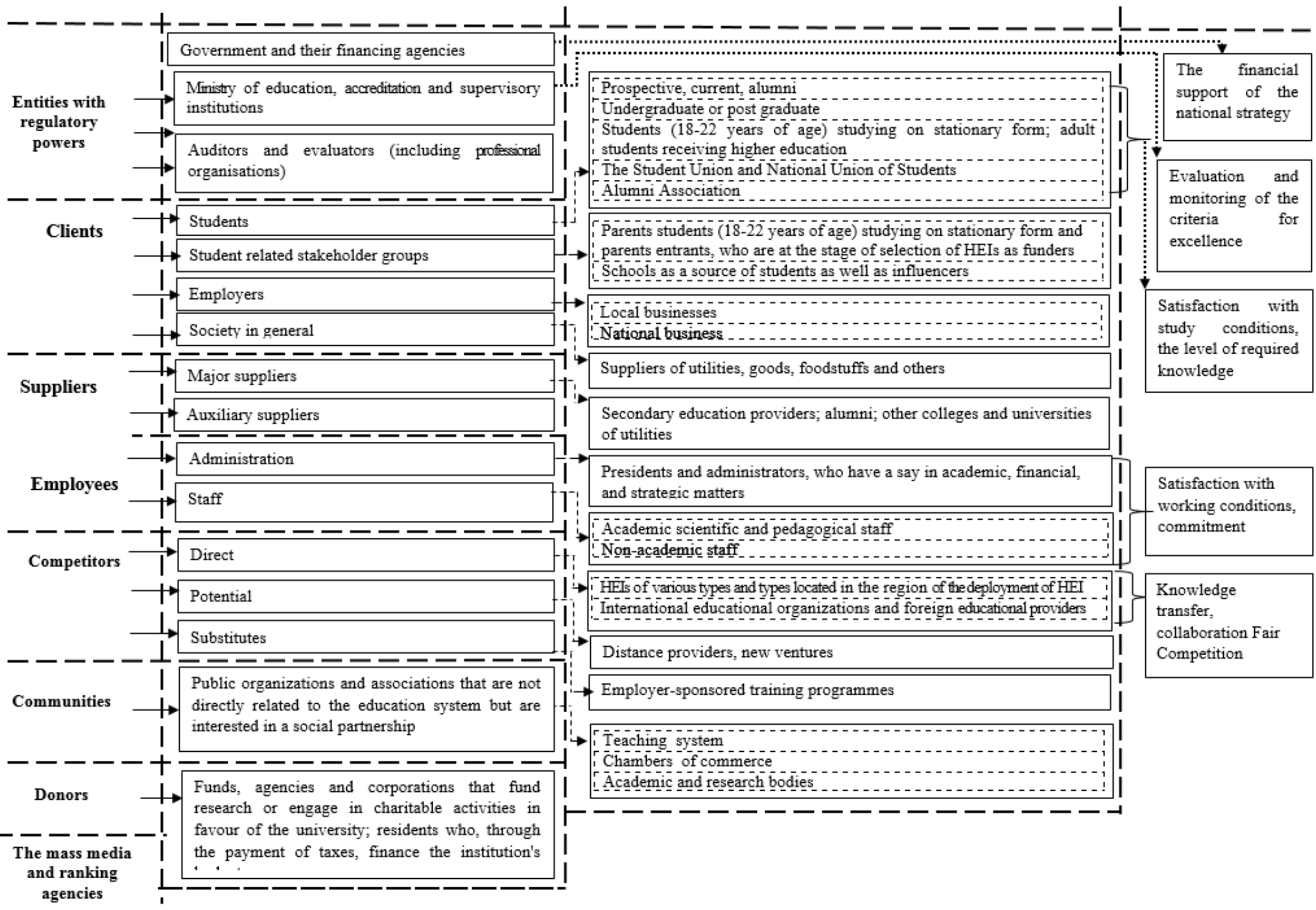

